\title{
Analyses of Hungarian sour cherry germplasm with simple sequence repeat markers
}

\author{
György, Z. ${ }^{1}$, Szabó, T. ${ }^{2}$, Nyéki, J. ${ }^{3} \&$ Pedryc, A. ${ }^{1}$ \\ ${ }^{1}$ Corvinus University of Budapest, Faculty of Horticultural Science, Department of Genetics and Plant Breeding, \\ 1118 Budapest, Ménesi út 44., Hungary \\ ${ }^{2}$ Újfehértó Fruit Growing Research and Extension Public Company \\ ${ }^{3}$ University of Debrecen CAS, Institute for Extension and Development, 4032, Debrecen, Böszörményi út 138,
} Hungary

\begin{abstract}
Summary: Twenty-four sour cherry cultivars (genotypes), belonging to four cultivar groups were fingerprinted using microsatellite markers. All genotypes have been arisen from the Carpathian basin, which could be secondary gene centre of sour cherry, since its progenitor species, ground cherry and sweet cherry overlap here. Five SSR primer pairs, earlier used for fingerprinting Turkish sour cherry germplasm were tested. None of the five primer pairs showed any polymorphism within the cultivar groups. The primer pairs were able to distinguish between the cultivar groups. The Oblacsinszka and the Cigánymeggy cultivar groups were the most difficult to separate, while the Pándy cultivar group was the most distinguishable.
\end{abstract}

Key words: cultivar groups, sour cherry, SSR markers

\section{Introduction}

Sour cherry (Prunus cerasus or Cerasus vulgaris) belongs to the family Rosaceae subfamily Prunoideae. It is a tetraploid species (Darlington 1927, Kobel 1927); supposedly it has arisen by the crossing of the diploid Prunus avium and/or the tetraploid Prunus fruticosa and/or Prunus frutescens in the Near East or in the area of the Caucasus (Olden \& Nybom, 1968). Prunus avium is an insectpollinated allogamous species with the capacity for vegetative dispersal by suckering (Frascaria et al. 1993).

The Carpathian basin - and so Hungary - can be a secondary gene centre of sour cherry, because its progenitor species, ground cherry and sweet cherry overlap here. The spontaneous crossing of these species can be the reason for the numerous variation of sour cherry found country-wide. Sour cherry is known for more than 1000 years in Hungary. The local population has domesticated, selected and propagated sour cherry from the wild material and many landraces has arisen. The most prevalent landraces in Hungary are "Pándy", "Cigánymeggy", "Bosnyák meggy". The Hungarian sour cherry landraces represent a wide diversity in fruit size, fruit colour and also in ripening time (Szabó, 2008). Several descriptions have been published about the Hungarian cultivars arisen from the above landraces (Hrotkó, 2003).

Until now the genetic relationship among the Hungarian sour cherry germplasm has not yet been investigated, and there are no reports about the genetic fingerprinting of it. The tetraploid cherry germplasm in the United States Department of Agriculture, Agricultural Research Service (USDA-ARS) collection was fingerprinted using 10 SSR markers (Love et al. 1990, Weber \& May 1989). These SSR primer pairs were able to differentiate among almost all accessions available in the collection. Sixteen Hungarian cultivars were also included in the USDA-ARS collection. The aim of the present study was to analyse some Hungarian cultivars arose from the sour cherry germplasm of the Carpathian basin.

\section{Materials and methods}

We investigated 24 Hungarian sour cherry cultivars and clones (Table 1), which were collected in the Fruit Research Station of Újfehértó. The examined material belongs to the Pándy, Cigány, Bosnyák and Oblacsinszka cultivar groups. DNA was extracted from buds in March, 2009 using the Qiagen DNeasy Plant Mini Kit (Biomarker, Hungary). DNA concentration and quality was assessed using NanoDrop (BioScience, Hungary) and on 1\% agarose gel. The SSR data for the already fingerprinted Hungarian cultivars was obtained from the following website: http://www.ars. usda.gov/Aboutus/docs.htm?docid=6307. These data were combined with the data obtained from our experiments.

PCR was performed in 251 reaction volume containing 20-80 ng DNA, 10X PCR reaction buffer, $2.5 \mathrm{mM} \mathrm{MgCl}$, $0.02 \mathrm{mM}$ dNTP mix, $2.5 \mathrm{~mol}$ of each 5' and 3' end primers, 1 unit of Taq DNA polymerase (Fermentas, Szeged, 
Table 1. The sour cherry genotypes used

\begin{tabular}{|c|c|c|}
\hline Nr. & Cultivar & Cultivar group \\
\hline 1 & Érdi bőtermő & \multirow{9}{*}{ Pándy } \\
\hline 2 & Újfehértói fürtös & \\
\hline 3 & Debreceni bőtermő & \\
\hline 4 & Kántorjánosi 3 & \\
\hline 5 & Éva (T) & \\
\hline 6 & $\mathrm{D}$ & \\
\hline 7 & Petri /R/ & \\
\hline 8 & Pándy 279 & \\
\hline 9 & Pándy BB 119 & \\
\hline 10 & Cigány 59 & \multirow[t]{2}{*}{ Cigány } \\
\hline 11 & Cigány (404) & \\
\hline 12 & Oblacsinszka 3/24 & \multirow{3}{*}{ Oblacsinszka } \\
\hline 13 & Oblacsinszka 3/133 & \\
\hline 14 & Erika (3/142) & \\
\hline 15 & $\mathrm{VN}-1$ & \multirow{4}{*}{ Bosnyák } \\
\hline 16 & VN-4 & \\
\hline 17 & VN-5 & \\
\hline 18 & VN-7 & \\
\hline 19 & A & \multirow{6}{*}{ Hibridek } \\
\hline 20 & $\mathrm{M}$ & \\
\hline 21 & $\mathrm{~N}$ & \\
\hline 22 & $\mathrm{~N}-2$ & \\
\hline 23 & Kései 22/70 & \\
\hline 24 & Maliga Emléke & \\
\hline
\end{tabular}

Hungary) and sterile distilled water. Five SSR primer pairs, previously isolated from the Prunoideae subfamily (Table 2) and used for fingerprinting Turkish sour cherry germplasm (Kacar et al. 2006) were used for the DNA amplification. PCR was carried out in a PTC 200 thermocycler (MJ Research, Budapest, Hungary) using the program consisting of an initial denaturation step at $94^{\circ} \mathrm{C}$ for $4 \mathrm{~min}$, followed by 25 cycles of $1 \mathrm{~min}$ at $94^{\circ} \mathrm{C} ; 1 \mathrm{~min}$ at $50-58^{\circ} \mathrm{C}$ (depending on the primer used); $1 \mathrm{~min}$ at $72{ }^{\circ} \mathrm{C}$, followed by a $7 \mathrm{~min}$ elongation step at $72{ }^{\circ} \mathrm{C}$. For the primer pairs pchpgms3, PceGA25 and PMS49 $58{ }^{\circ} \mathrm{C}$ annealing temperature was used, while for PMS3 the annealing temperature was $55{ }^{\circ} \mathrm{C}$ and for PS08E08 the annealing temperature was $50^{\circ} \mathrm{C}$. The PCR products were applied on a $1 \%(\mathrm{w} / \mathrm{v})$ ethidium bromidestained agarose gel with xylencyanol loading buffer to verify the occurrence of the amplification.

The amplified DNA fragments were separated on $8 \%$ polyacrylamide gel at $80 \mathrm{~W}\left(55^{\circ} \mathrm{C}\right)$ for $2-3 \mathrm{~h}$ (depending on

Table 2. SSR locus designation, the sequence of the oligos and the sources of the primers used

\begin{tabular}{|c|c|c|c|c|}
\hline primer & orientation & Oligo sequence (5' to 3') & Reference & Source \\
\hline PMS 3 & $\begin{array}{l}\mathrm{F} \\
\mathrm{R}\end{array}$ & $\begin{array}{l}\text { TGGACTTCACTCATTTCAGAGA } \\
\text { ACTGCAGAGAATTTCACAACCA }\end{array}$ & Cantini et al. & $\begin{array}{l}\text { Sweet } \\
\text { cherry }\end{array}$ \\
\hline PMS49 & $\begin{array}{l}\mathrm{F} \\
\mathrm{R}\end{array}$ & $\begin{array}{l}\text { TCACGAGCAAAAGTGTCTCTG } \\
\text { CACTAACATCTCTCCССТCCC }\end{array}$ & Cantini et al. & $\begin{array}{l}\text { Sweet } \\
\text { cherry }\end{array}$ \\
\hline PS08E08 & $\begin{array}{l}\mathrm{F} \\
\mathrm{R}\end{array}$ & $\begin{array}{l}\text { CCCAATGAACAACTGCAT } \\
\text { CATATCAATCACTGGGATG } \\
\end{array}$ & Sosinski et al. & $\begin{array}{l}\text { Sweet } \\
\text { cherry }\end{array}$ \\
\hline PceGA25 & $\begin{array}{l}\mathrm{F} \\
\mathrm{R}\end{array}$ & $\begin{array}{l}\text { GCAATTCGAGCTGTATTTCAGATG } \\
\text { CAGTTGGCGGCTATCATGCTTAC }\end{array}$ & Cantini et al. & $\begin{array}{l}\text { Sour } \\
\text { cherry }\end{array}$ \\
\hline pchpgms3 & $\begin{array}{l}\mathrm{F} \\
\mathrm{R}\end{array}$ & $\begin{array}{l}\text { ACGCTATGTCCGTACACTCTCCATG } \\
\text { CAACCTGTGATTGCTCCTATTAAAC }\end{array}$ & Sosinski et al. & peach \\
\hline
\end{tabular}

the primer pair), and stained with a simple silver staining method (Bassam and Gresshoff, 2007). Amplified fragments were scored visually and the fragment sizes were estimated on the basis of the fragment sizes of the earlier fingerprinted Hungarian sour cherry cultivars. DNA amplification, polyacrilamide gel separation and scoring were repeated at least in two independent experiments for all samples to confirm repeatability of the results.

\section{Results and discussion}

All five primer pairs produced discrete reproducible fragments for all genotypes investigated (Figures 1-5). The number of fragments amplified from an individual sour cherry genotype with each primer pair ranged from two to four. Four fragments per primer pair are the maximum number expected if the primer pair amplified different size fragments from duplicate loci present in tetraploid sour cherry.

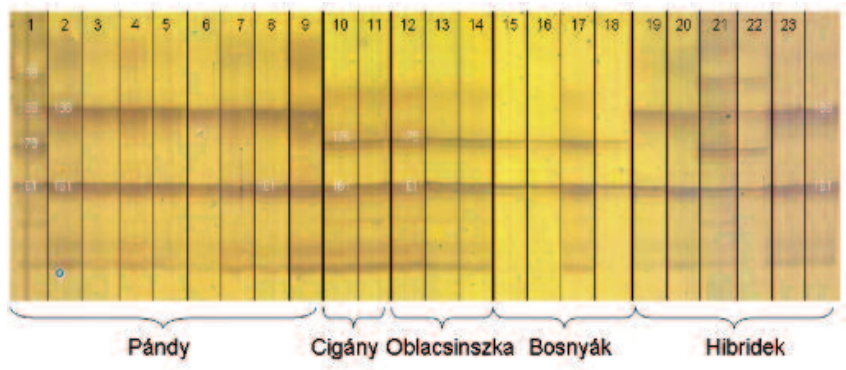

Figure 1. Silver stained microsatellite DNA profiles of the 24 investigated Hungarian sour cherry cultivars with primer pair PceGA25

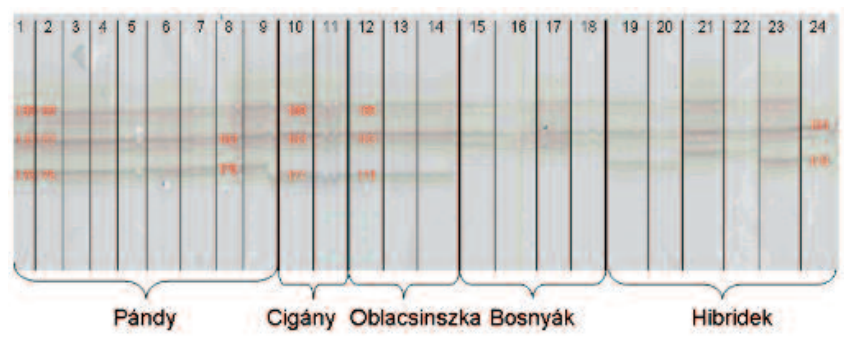

Figure 2. Silver stained microsatellite DNA profiles of the 24 investigated Hungarian sour cherry cultivars with primer pair pchmgms

The five SSR primer pairs used produced 24 different fragments with an average of 4.8 putative alleles per locus. The number of putative alleles per locus ranged from three to six. Sizes ranged from $122 \mathrm{bp}$ to $198 \mathrm{bp}$ (Table 3).

The primer pair PMS3 (isolated from sweet cherry) was the most informative as 6 putative alleles were identified. The range of putative alleles per SSR (3-6) however was much lower than in the survey of Kacar et al. (2006), where with the same five primer pairs 5-20 putative alleles were identified in the Turkish sour cherry germplasm. The low level 
Figure 3. Silver stained microsatellite DNA profiles of the 24 investigated

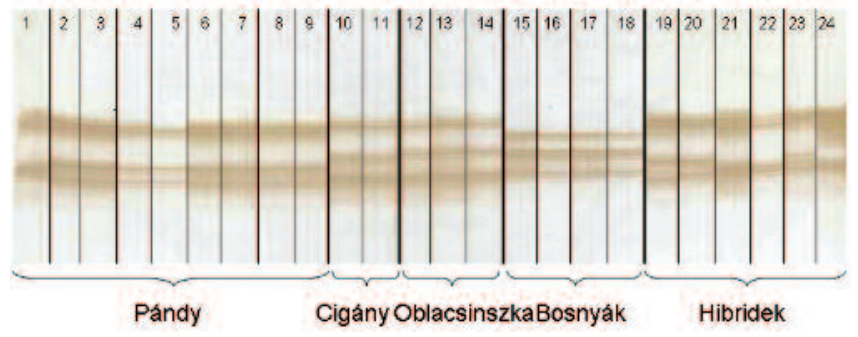

Figure 4. Silver stained microsatellite DNA profiles of the 24 investigated Hungarian sour cherry cultivars with primer pair PMS3

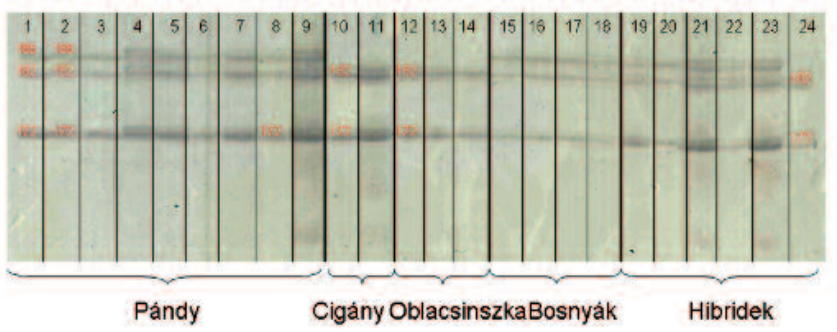
Hungarian sour cherry cultivars with primer pair PS08E08

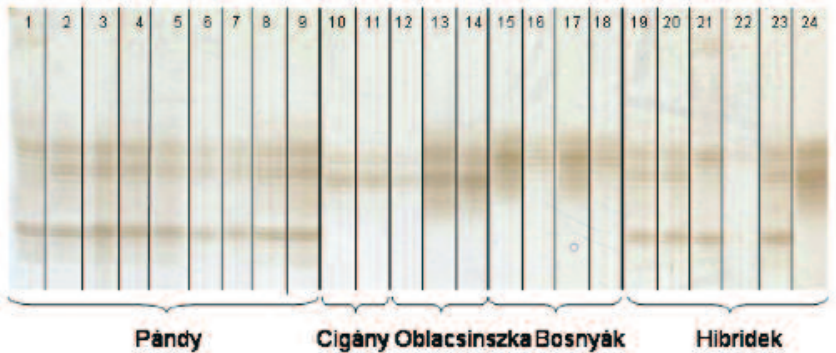

Figure 5. Silver stained microsatellite DNA profiles of the 24 investigated Hungarian sour cherry cultivars with primer pair PMS49

Table 3. Number and fragment size of the obtained fragments with the five SSR primer pairs

\begin{tabular}{|l|c|l|}
\hline Primer pair & Total number of fragments & Fragment sizes (bp) \\
\hline PMS 3 & 5 & \\
\hline PMS49 & 5 & $122,136,142,144,185$ \\
\hline PS08E08 & 3 & $172,182,185$ \\
\hline PceGA25 & 5 & $161,173,175,186,198$ \\
\hline pchpgms3 & 4 & $174,176,183,189$ \\
\hline
\end{tabular}

of polymorphism detected in this study probably reflects a narrow genetic base in the fingerprinted Hungarian germplasm. The same phenomena was observed when fingerprinting the Hungarian apricot germplasm, where against the spectacular morphological diversity only low polymorphism concerning the genetic background

Table 4. Fragment lengths of the Hungarian sour cherry cultivars found in the USDA-ARS tart cherry SSR database. The fragments assigned with bold letters were not detected in the present study, while fragments assigned with bold and in italics were not included in the USDA-ARS tart cherry SSR database

\begin{tabular}{|c|c|c|c|c|c|c|}
\hline Nr. & Cultivar & pchpgms3 & PS08E08 & PMS49 & PMS3 & PceGA25 \\
\hline 1 & Érdi bőtermő & $189,183,178$ & $185,182,172$ & 185,122 & $195,177,175$ & $198,186,173,161$ \\
\hline 2 & Újfehértói fürtös & $189,183,176$ & $184,182,172$ & $122,144 ?$ & $180,177,175$ & $185, \mathbf{1 7 3}, 161$ \\
\hline 8 & Pándy 279 & $183,176,189$ & $172,182,185$ & $122,144 ?$ & $-, 180,175$ & $161, \mathbf{1 4 5}, 185$ \\
\hline 10 & Cigány 59 & $189,183,174$ & 182,172 & $136,79,144 ?$ & $185,175,155$ & 175,161 \\
\hline 12 & Oblacsinszka & $189,183,174$ & 182,172 & $136,144 ?$ & $186,177,175$ & $175,173,161$ \\
\hline 24 & Mailga emléke & 183,176 & 182,172 & 144,136 & $200,197,180,175$ & $195,186,161$ \\
\hline
\end{tabular}
was detected (Pedryc et al. 2009).

The primer pairs pchpgms3, PceGA25, PMS 49 and PMS3 were able to differentiate the "Pándy" cultivar group, while the primer pairs pchpgms3, PMS49 and PMS3 were able to separate the "Bosnyák" cultivar group. The cultivar groups "Cigány meggy" and "Oblacsinszka" could not be separated from each other with any of the five tested primer pairs.

The genotypes "A", "M", "N", N-2" are probably hybrids of "Újfehértói fürtös" and "Érdi bőtermő" (Szabó, 2009). The primer pair PMS49 amplified one (185), while the primer pair PceGA25 amplified two extra fragments in case of "N", "N-2" and "Érdi bőtermő" (198 and 173) beside of the other fragments, which were present in all members of the "Pándy" group. The presence of the same extra alleles may confirm the assumption that " $\mathrm{N}$ " and "N-2" are hybrids of "Újfehértói fürtös" and "Érdi bőtermő".

The results obtained in this study compared to the USDAARS tart cherry collection SSR database differ in some fragments; the comparison is shown in Table 4. Especially in case of "Pándy 279" we detected new alleles compared to the tart cherry database with all primer pairs. This difference may be explained by possibility that cultivars used in the two studies were not identical.

In general, as it is well observable in Figure 1, none of the five primer pairs used were able to differentiate within the cultivar groups. This can be explained by the fact that for hundreds of years the most popular genotypes were propagated vegetatively and small mutations could occur, which were then preserved under a new cultivar name. The "Pándy" group was most often well separated, while the cultivar groups "Cigánymeggy" and "Oblacsinszka" were the least distinguishable.

\section{References}

Bassam, B.J. \& Gresshoff P.M. (2007): Silver staining DNA in polyacrylamide gels. Nature Protocols, 2 (11): 2649-2654.

Cantini, C., Iezzoni, A.F., Lamboy, W., Boritzki, M. \& Struss, D. (2001): DNA fingerprinting of tetraploid cherry germplasm using simple sequence repeats. J. Amer. Soc. Hort.Sci., 126: 205-209.

Darlington, CD (1927): The behaviour of polyploids. Nature, 119: 390-391.

Frascaria, N., Santi, F. \& Gouyon, P.H. (1993): Genetic differentiation within and among populations of chestnut (Castanea sativa Mill.) and wild cherry (Prunus avium L.). Heredity, 70: 634-641.

Hrotkó, K. (2003): Cseresznye és meggy. Mezőgazda, Budapest 
Kacar, Y.A., Cetiner, S.M., Cantini C. \& Iezzoni, A.F. (2006): Simple sequence repeat (SSR) markers differentiate Turkish sour cherry germplasm. Journal of the American Pomological Society, 60 (3): 136-143.

Kobel, F. (1927): Zytologische Untersuchungen an Prunoideen und Pomoideen. Arch Julius Klaus-Stift Vererbforsch, 3: 1-84.

Love, J.M., Knight, A.M., McAleer, M.A. \& Todd, J.A. (1990): Towards construction of a high resolution map of the mouse genome using PCR-analysed microsatellites. Nucleic Acids Res., 18: 4123-4130.

Olden, E.J. \& Nybom, N. (1968): On the origin of Prunus cerasus L. Hereditas, 59: 327-345.
Pedryc, A., Ruthner, S., Hermán, R., Krska, B., Heged S. A. \& Halász, J. (2009): Genetic diversity of apricot revealed by a set of SSR markers from linkage group G1. Scientia Horticulturae, 121: 19-26.

Sosinski, B., Gannavarapu, M., Hager, L.D., Beck, L.E., King, G.J., Ryder, C.D., Rajapakse, S., Baird, W.V., Ballard, R.E. \& Abott, A.G. (2000): Characterisation of microsatellite markers in peach. Theor. Appl. Genet., 97: 264-272.

Szabó, T. (2008): Az északkelet-magyarországi meggy tájfajta szelekció eredményei és gazdasági jelentőssége

Weber, J.L. \& May, P.E. (1989): Abundant class of human DNA polymorphism which can be typed using the polymerase chain reaction. Am. J. of Human Gen., 44: 388-396. 